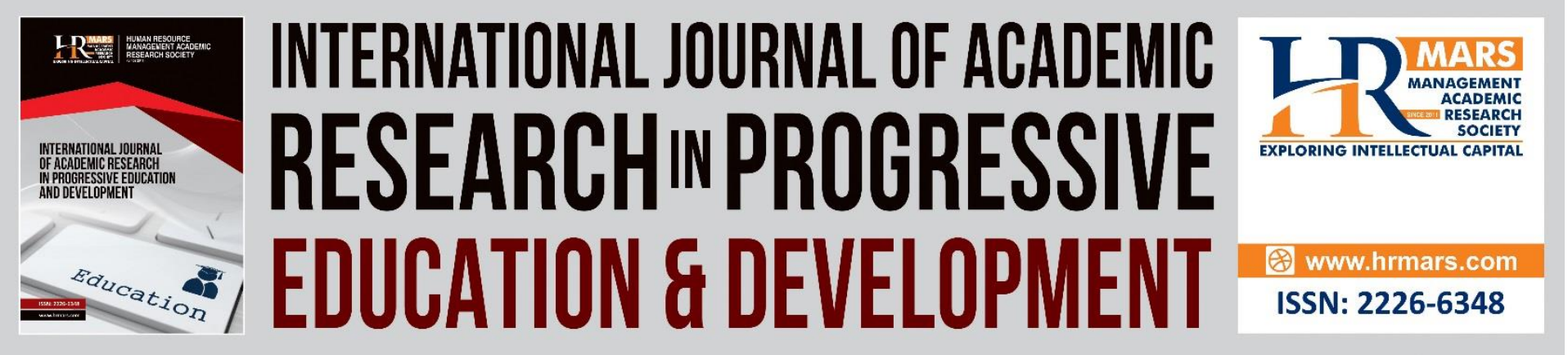

\title{
Development of Financial Education Training Module for Secondary School Mathematics Teachers: Design and Development Research
}

Norazura Said, Chew Cheng Meng, Muzirah Musa, Muhammad Nidzam Yaakob

To Link this Article: http://dx.doi.org/10.6007/IJARPED/v11-i1/12342 DOI:10.6007/IJARPED/v11-i1/12342

Received: 14 November 2021, Revised: 17 December 2021, Accepted: 03 January 2022

Published Online: 20 January 2022

In-Text Citation: (Said et al., 2022)

To Cite this Article: Said, N., Meng, C. C., Musa, M., \& Yaakob, M. N. (2022). Development of Financial Education Training Module for Secondary School Mathematics Teachers: Design and Development Research. International Journal of Academic Research in Progressive Education and Development, 11(1), 827-836.

Copyright: (C) 2022 The Author(s)

Published by Human Resource Management Academic Research Society (www.hrmars.com)

This article is published under the Creative Commons Attribution (CC BY 4.0) license. Anyone may reproduce, distribute, translate and create derivative works of this article (for both commercial and non-commercial purposes), subject to full attribution to the original publication and authors. The full terms of this license may be seen at: http://creativecommons.org/licences/by/4.0/legalcode

Vol. 11(1) 2022, Pg. 827 - 836

Full Terms \& Conditions of access and use can be found at http://hrmars.com/index.php/pages/detail/publication-ethics 


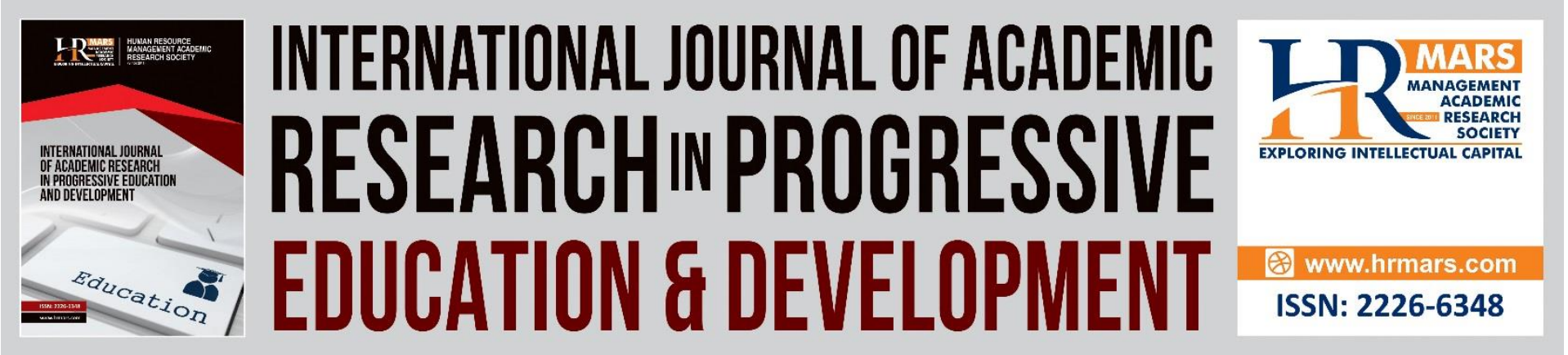

\title{
Development of Financial Education Training Module for Secondary School Mathematics Teachers: Design and Development Research
}

\author{
Norazura Said ${ }^{1}$, Chew Cheng Meng'르. Muzirah Musa ${ }^{3}$, \\ Muhammad Nidzam Yaakob ${ }^{4}$ \\ 'Universiti Sains Malaysia, Malaysia, ${ }^{2}$ Universiti Sains Malaysia, Malaysia, ${ }^{3}$ Universiti Sains \\ Malaysia, Malaysia, ${ }^{4}$ Teacher Training College (IPG), Darulaman Campus, Malaysia, \\ Email: norazurasaid2020@gmail.com,cmchew@usm.my, muzirah@usm.my, \\ nidzam@ipda.edu.my
}

\begin{abstract}
This is developmental research with the purpose of elucidating the methodology used to design a financial education training module for secondary school mathematics teachers. Currently, the Ministry of Education Malaysia and Bank Negara Malaysia have entered into a partnership to integrate financial education into the school curriculum. However, there is a lack of specialised modules on teaching financial education for secondary school mathematics teachers. Appointed mathematics teachers need to have specific training modules to enable them to perform quality teaching strategies. Thus, this study proposes a design research approach, Design and Development (DDR), that is, a research approach to multi-method development. Using DDR, this study will go through three phases of study and use several different study tools in each phase. The involvement of study participants from expert groups and user groups can provide a variety of inputs and take into account the needs of the module. Therefore, the findings provided useful evidence of potential in designing and developing a financial education training module for secondary school mathematics teachers. Keywords: Financial Education, Design and Development (DDR), Training Module, Mathematics

\section{Introduction}

Financial education should be applied to every individual, including young people who are still learning to achieve financial well-being when they become adults. Financial education is an important element of the 21st Century, and a financially literate society plays a role in the development and economic stability to build a prosperous nation (OECD/INFE, 2018). Many nations have created initiatives to incorporate financial education (FE) material into the school curriculum in response to the low levels of financial literacy among young people (Güvenç, 2017; Julius et al., 2020; McGregor, 2018; Salas-Velasco et al., 2020). While adults make the majority of financial choices, it is recognised that financial literacy must be fostered in schools to ensure that pupils gain the skills necessary to handle their finances successfully
\end{abstract}


in adulthood (Novieningtyas, 2018). The application of the elements of Financial Education aims to form the future generation capable of making wise financial decisions, practising ethical financial management and being skilled in managing financial affairs responsibly (Ministry of Education Malaysia, 2018). The implementation of financial education is covered in the Curriculum and Assessment Standards Document (DSKP) for the Primary School Standard Curriculum (KSSR) and the Secondary School Standard Curriculum (KSSM). This aligns with the National Financial Literacy Strategy 2019-2023, which sets out key strategies to extend the basic elements of financial education in the school curriculum from preschool, primary school to secondary school (Financial Education Network, 2019).

Ministry of Education Malaysia has taken a comprehensive step by integrating financial education elements in the Curriculum and Assessment Standards Document (DSKP) Primary School Standard Curriculum (KSSR) and Secondary School Standard Curriculum (KSSM) through several subjects, including mathematics. This effort aims to develop Malaysians who are financially literate and able to manage their finances wisely and effectively. Financial education has been introduced at the secondary school level through a new topic in the Mathematics curriculum, namely Consumer Mathematics: Investment Savings, Credit and Debit starting 2017 for form three students. Consumer Mathematics learning is continued into the following year through the topic of Financial Management in form four. During form five, students are introduced to the topic of insurance and taxation.

Teaching and learning of Consumer Mathematics topics apply many problem-solving questions that require students to think outside the box. If observed, this topic of Consumer Mathematics highlights things that are very synonymous and directly related to daily life. For example, pupils will be educated and taught about the different types of savings and their calculations. It is hoped that they will be able to know the types of investments such as stock investments, real estate, and unit trusts even at an early stage to be better prepared before entering the world of work. In addition, there is also a discussion on the pros and cons of using credit cards and personal loans. At the end of the lesson, students are expected to be able to apply and evaluate their knowledge related to prudent financial management for their future (Ministry of Education Malaysia, 2018).

\section{Problem Statement}

In PISA 2018, the OECD defines financial education as a process that enables financial consumers to increase their understanding of financial products, concepts, and risks. Through proper information, guidance and advice, they can develop skills and confidence to become more aware of risks and opportunities. This also includes being able to make wise choices, know the channels for seeking help and take effective actions to improve their financial wellbeing (OECD \& GFLEC, 2018). Financial literacy is an international level assessment in PISA taken by Malaysian students aged 15 years and above, starting with the PISA cycle 2021 (Ministry of Education Malaysia, 2018). The OECD (2018) reported the results of a financial literacy assessment involving approximately 2900015 -year-old students in 13 OECD countries and economies (Australia, Belgian Flemish Community, Czech Republic, Estonia, France, Israel, Italy, New Zealand, Poland, The Slovak Republic, Slovenia, Spain and the United States) show still low levels of financial education among students. This report is in line with the findings of previous studies that found the level of financial literacy of secondary school students is low (Amagir et al., 2019; Arceo-Gómez \& Villagómez, 2017; Belás et al., 2016; Butters et al., 2012; Cameron et al., 2014; Helen \& Ilias, 2019; Liu et al., 2019) whereas basic knowledge of finance is important for students to plan good financial management. 
The aspect of prudent financial management among Malaysians is currently at an alarming level. Individuals from the younger generation were found to fail to manage and administer finances and were more likely to have financial problems (Malaysian Department of Insolvency, 2020). According to statistics from the Malaysian Department of Insolvency, 64,632 Malaysians aged between 18 and 44 have been declared bankrupt in the last five years (AKPK, 2018). They were declared bankrupt due to vehicle hire purchase debts, failure to repay housing loans, excessive credit card debt, failure to settle personal and business loans, and those who are guarantors to corporate and social. This bankruptcy shows that young people are still unable to take appropriate steps to avoid becoming bankrupt at such a young age. Therefore, the question is raised about the level of financial literacy of young people in this country, namely whether they are competent enough in managing their finances.

MOE strives to address the problem of financial literacy among the younger generation. Still, these efforts are in vain without the support, cooperation and close collaboration of parents, teachers and students (Financial Education Network, 2019). Studies abroad report that teachers and parents are not ready to deliver financial management education to high school students. This is because they themselves lack the formal training to deliver financial management education. Teachers were found to be unprepared and unconvinced to teach about financial management education, where only one-third of teachers considered themselves competent enough to provide financial education (De Beckker et al., 2019). A research finding by Sawatzki and Sullivan (2017) also points to teachers being aware of the importance of delivering financial management education to students with learning difficulties. Still, they admitted to having difficulty in conveying information. Teachers perceive they lack teaching experience and need to prepare for better financial literacy and teaching so that students gain more meaningful and valuable educational experiences (Ferrer, 2018; Henning \& Lucey, 2017; Imelda et al., 2017; Matheson et al., 2020). The above finding is consistent with the study by Tanase and Lucey (2017) examined that the majority of preservice teachers have a narrow or moderate concept of the relationship between mathematics and financial literacy. Thus, there is a need to understand mathematics and financial terminology.

A similar finding was obtained in Malaysia, where most teachers and parents seem less prepared to deliver financial management education to school children. Several studies have revealed that some teachers have poor financial behaviour patterns (Aladdin \& Ahmad, 2017; Zaimah et al., 2012). Additionaly, Compen et al (2021) study suggested that financial literacy exposure to teacher students should be more extensive such as holding financial literacy workshops to strengthen the knowledge and skills of teacher students. In addition, most teachers $(81.5 .7 \%)$ stated that there should be a financial management education module specific to the topic of consumer mathematics: financial management in form 4 (Ramli \& Mohd Tajudin, 2021).

Therefore, it is important to develop financial education training modules for secondary school mathematics teachers. Teachers can educate secondary school students to help them manage finances well when they become adults. This study was conducted to provide a clear picture to researchers and educational policymakers about developing a mathematics finance education training module for secondary school mathematics teachers conducted based on design and development research (DDR) methods. 
DEVELOPMENT

Vol. 11, No. 1, 2022, E-ISSN: 2226-6348 ㄷ 2022 HRMARS

\section{Methodology}

The study design is the main planning and strategy in answering the research questions submitted through data collection and analysis procedures (Cohen et al., 2017). This study was conducted using Design and Development Research (DDR). Moreover, Richey and Klein (2007) backed this DDR approach, who explained that a development study covers an orderly and systematic process. DDR can be used to test the theory and the practical applicability of a model, module or product. Therefore, the study uses an approach. This DDR is also said to be suitable for the design development of various fields of study, including learning strategies, program development, model development and product development (Beram et al., 2020; Jamil et al., 2015).

DDR approach directly involves problem-solving criteria, guided by literature and empirical, as well as being able to contribute something to the development field of science. This statement is further confirmed by Richey and Klein (2007), who explained that this DDR-based study had to go through four phases of a study comprehensive namely:

i. The needs analysis phase is the first phase,

ii. The design phase as the second phase,

iii. The development phase is the third phase, and

iv. The usability assessment or testing phase becomes the fourth phase.

However, in practice, this study was conducted through three phases, namely, by combining the second and third phases as a study phase as suggested by (Siraj et al., 2013). Therefore, this condition does not affect the procedure and the number of phases studies such as those presented by Richey and Klein (2007) for DDR -based studies. Tracing this development-based study, Richey et al (2004); van den Akker et al (2006) concluded that developmental studies could be classified into first and second types. The first type involves the development of a product or program-specific, while the second type involves the development of processes, equipment or models. The basic framework of the methods used in the DDR-based study can be shown in Table 1 as follows:

Table 1. Summary of Design and Development Research Accordingly to the Phase

\begin{tabular}{|c|c|c|}
\hline Type of Research & Project Emphasis & Research Methods Employed \\
\hline Product \& Tool & Comprehensive Design & Case study, Content Analysis, Evaluation, \\
\hline Research & \& Development Projects & Field Observation, In-Depth Interview \\
\hline Product \& Tool & Phases of Design \& & Case Study, Content Analysis, Expert \\
\hline Research & Development & $\begin{array}{l}\text { Review, Field Observation, In-Depth } \\
\text { Interview, Survey Product }\end{array}$ \\
\hline $\begin{array}{l}\text { Product \& Tool } \\
\text { Research }\end{array}$ & Tool Development \& Use & $\begin{array}{l}\text { Evaluation, Expert Review, In-Depth } \\
\text { Interview, Survey }\end{array}$ \\
\hline Model Research & Model Development & $\begin{array}{l}\text { Case Study, Delphi, In-Depth Interview, } \\
\text { Literature Review, Survey, Think-Aloud } \\
\text { Methods }\end{array}$ \\
\hline Model Research & Model Validation & $\begin{array}{l}\text { Experimental, Expert Review, In-Depth } \\
\text { Interview }\end{array}$ \\
\hline Model Research & Model use & $\begin{array}{l}\text { Case Study, Content Analysis, Field } \\
\text { Observation, In-Depth Interview, Survey, } \\
\text { Think-Aloud Methods }\end{array}$ \\
\hline
\end{tabular}

Sources: Adapted from Richey and Klein (2007, p. 46) 
Table 1 shows the types of studies, approaches and methods used in performing studies using DDR. Based on Table 1, it can also be seen that using DDR and research can be done by applying several research methods in accordance with the objectives and questions of the study posed. Obviously, DDR allows the use of various research methodologies, either qualitatively, or quantitative, or a combination of both, in each phase of the study (Richey \& Klein, 2007). Nowadays, other methods can also be implemented in DDR studies, including Fuzzy Delphi Method (FDM), Interpretive Structural Modeling (ISM), Nominal Group Technique (NGT), Partial Least Square Structural Equation Modeling (PLS-SEM), Structural Equation Modeling (SEM), Analytical Hierarchal Processing (AHP), and Social Networking Analysis (SNA) (Siraj et al., 2013).

To achieve the goal of developing a module, Richey and Klein (2007) suggests using a multiple method approach in each phase of the study. DDR -based studies also emphasise the validity of the model through either internal or external validations. Validity of the interior of the developed model can be obtained either through view experts, document usability or research on model components. Internal validity refers to the validity of the components of the model developed (Siraj et al., 2020).

As for external validity, it is obtained through field evaluation or experimental testing. External validation was performed to assess the impact of the model developed (Richey \& Klein, 2007; Siraj et al., 2013). Along with the above DDR related statements and highlights, this study is framed using three study phases. This includes the needs analysis phase, design and development phase, and usability testing phase of the model. The study design process of the development of this financial education training module can be illustrated in Table 2 as follows:

Table 2. Summary of Design and Development Research Accordingly to the Phase

\begin{tabular}{|c|c|c|c|}
\hline Research Phase & Instruments & Data Analysis & Expected outcomes \\
\hline $\begin{array}{l}\text { Phase one: } \\
\text { Need Analysis } \\
\text { Phase }\end{array}$ & $\begin{array}{l}\text { Quantitative: } \\
\text { Survey }\end{array}$ & $\begin{array}{l}\text { Data analysis are using } \\
\text { Statistical Package for Social } \\
\text { Science (SPSS) Version } 27.0 \text {. } \\
\text { Interpretation means } \\
\text { analysis was used to } \\
\text { determine the teachers need } \\
\text { financial education training } \\
\text { module }\end{array}$ & $\begin{array}{l}\text { Finding shows } \\
\text { teachers are in need } \\
\text { Regarding financial } \\
\text { education training } \\
\text { module. }\end{array}$ \\
\hline Phase two: & Fuzzy Delphi & Threshold $(\mathrm{d}) \leq 0.2$ & Design and \\
\hline Design and & Method (FDM) & Experts' consensus & development \\
\hline Development & $\begin{array}{l}\text { FDM 1-Main } \\
\text { Constructs } \\
\text { FDM 2- Elements in } \\
\text { main constructs. }\end{array}$ & $\begin{array}{l}\text { percentage } \\
\geq 75 \% \text { and } \alpha \text {-cut } \geq 0.5\end{array}$ & $\begin{array}{l}\text { prototypes of the } \\
\text { financial education } \\
\text { training module. }\end{array}$ \\
\hline $\begin{array}{l}\text { Phase three: } \\
\text { Evaluation Phase }\end{array}$ & $\begin{array}{l}\text { Nominal Group } \\
\text { Technic (NGT) }\end{array}$ & $\begin{array}{l}\text { The researcher will collect } \\
\text { the data through NGT } \\
\text { evaluation session }\end{array}$ & $\begin{array}{l}\text { Show expert } \\
\text { agreement of more } \\
\text { than } 70 \% \text { against all } \\
\text { items found in the } \\
\text { financial education } \\
\text { training module. }\end{array}$ \\
\hline
\end{tabular}


The participants in this study were instructors, secondary school mathematics teachers and experts in the field of mathematics, financial education, curriculum and pedagogy. Adequate sample size or more precise sample strength should be a primary priority when designing a study. As defined by Cohen et al (2017), purposive sampling entails the deliberate selection of typical subjects who exhibit specified characteristics, comprehend, and possess information about the feature being examined. In this study, respondents in the need analysis phase are 67 secondary school mathematics teachers using purposive sampling. Phase 2, design and development, is the most critical in the DDR approach. This phase's primary objective is to design and develop a financial literacy training module for secondary school mathematics teachers. According to Adler and Ziglio (1996), the optimal number of experts to use in the Delphi technique is between ten and fifteen if there is a high degree of consistency across experts. At the same time, Jones and Twiss (1978) believe that there might be as many as ten to fifty specialists (Jamil \& Noh, 2020). Therefore, the researcher will pick a total of 12 experts for this study, including curriculum experts, speciality university lecturers, teacher training college lecturers, mathematics experts, and financial education experts. The evaluation phase is the final stage of the DDR approach. According to Richey and Klein (2007), this phase will assess the applicability and usability of the financial education training module. In this phase, the researcher used 30 experts Mathematics teachers as a sample; in Modified Nominal Group Technic (NGT). A fuller description of the NGT and its uses in a wide range of contexts is provided elsewhere (O’Neil \& Jackson, 1983).

\section{Discussion}

There are numerous techniques for developing a financial education training module. For example, studies can be undertaken using qualitative, quantitative, or a combination of qualitative and quantitative methodologies (mix method). However, after reviewing the pertinent literature and academic perspectives, it was determined that this design and development (DDR) study-based study might also be used as a method for developing the required module. The DDR-based investigations were found to be comprehensive, empirical, and systematic, utilising a variety of approaches throughout the research (Richey \& Klein, 2007).

It is obvious that each phase of the study will employ a single strategy to address the research objectives given. Indirectly, DDR is believed to be capable of resolving difficulties in certain circumstances (Siraj et al., 2013) and may be customised utilising cutting-edge research tools such as FDM, NGT, ISM, AHP, and SEM. However, DDR is still compatible with conventional quantitative or qualitative methodologies, as long as the study sample is either a user group or an expert group. Therefore, this training module development study will be able to add value to existing research methodologies by methodically including more DDR approaches and utilising a variety of research instruments.

\section{Conclusion}

To summarise, the design and development approach was used to create a financial education training module for mathematics teachers in order to tell policymakers about prospective teaching resources sought or envisioned by teachers who align with 21st-century abilities. The findings of this study will raise teachers' knowledge of the value of financial education training modules as a new source of teaching and learning as well as tools for their pedagogies. The three key aspects of the PST framework are taken into this study. The DDR approach enables the expansion and improvement of current knowledge in the numerous 
DEVELOPMENT

Vol. 11, No. 1, 2022, E-ISSN: 2226-6348 @ 2022 HRMARS

subjects examined. This training module also takes into account the Malaysian culture and demands, which may differ from those in the west.

\section{Corresponding Author}

Norazura Said

Universiti Sains Malaysia, Malaysia

Email: norazurasaid2020@gmail.com

\section{References}

Adler, M., \& Ziglio, E. (1996). Gazing into the oracle: The Delphi method and its application to social policy and public health. London: Jessica Kingsley Publishers.

AKPK. (2018). 64,632 Malaysians declared bankrupt over last 5 years. Agensi Kaunseling dan Pengurusan Kredit. Retrieved from https://www.akpk.org.my/news/1249-64632malaysians-declared-bankrupt-over-last-5-years

Aladdin, Y. H., \& Ahmad, A. (2017). Tahap literasi kewangan di kalangan mahasiswa. In Proceedings of the International Conference on Global Education V "Global Education, Common Wealth and Cultural Diversity" (pp. 2373-2387). Universitas Ekasakti, Padang, 10-11 April 2017.

Amagir, A., Groot, W., Maassen van den Brink, H., \& Wilschut, A. (2019). SaveWise: The design of a financial education program in The Netherlands. Citizenship, Social and Economics Education, 18(2), 100-120. https://doi.org/10.1177/2047173419870053

Arceo-Gómez, E. O., \& Villagómez, F. A. (2017). Financial literacy among Mexican high school teenagers. International Review of Economics Education, 24, 1-17. https://doi.org/10.1016/j.iree.2016.10.001

Belás, J., Nguyen, A., Smrčka, L., Kolembus, J., \& Cipovová, E. (2016). Financial literacy of secondary school students. Case study from the Czech Republic and Slovakia. Economics and Sociology, 9(4), 191-206. https://doi.org/10.14254/2071-789X.2016/9-4/12

Beram, S., Awang, M., \& Ismail, R. (2020). Pembangunan model kompetensi pemimpin pertengahan: Satu kajian reka bentuk dan pembangunan. Journal of Educational Research \& Indegenous Studies Journal, 2(1), 1-11.

Butters, R., Asarta, C., \& McCoy, S. (2012). Financial literacy and gender in US high schools. Journal of Economics and Finance Education, 11(2), 142-149.

Cameron, M. P., Calderwood, R., Cox, A., Lim, S., \& Yamaoka, M. (2014). Factors associated with financial literacy among high school students in New Zealand. International Review of Economics Education, 16(PA), 12-21. https://doi.org/10.1016/j.iree.2014.07.006

Cohen, L., Manion, L., \& Morrison, K. (2017). Research methods in education (8th ed.). Routledge. https://doi.org/10.4324/9781315456539

Compen, B., De Witte, K., \& Schelfhout, W. (2021). The impact of teacher engagement in an interactive webinar series on the effectiveness of financial literacy education. British Journal of Educational Technology, 52(1), 411-425. https://doi.org/10.1111/bjet.13013

De Beckker, K., Compen, B., De Bock, D., \& Schelfhout, W. (2019). The capabilities of secondary school teachers to provide financial education. Citizenship, Social and Economics Education, 18(2), 66-81. https://doi.org/10.1177/2047173419850152

Ferrer, J. C. (2018). Financial capability of public school teachers in the Philippines. EDUCARE: International Journal for Educational Studies, 11(1), 59-78.

https://doi.org/10.2121/edu-ijes.v11i1.1049 
Financial Education Network. (2019). Malaysia national strategy for financial literacy 20192023. Kuala Lumpur: Bank Negara Malaysia and Securities Commission Malaysia.

Güvenç, H. (2017). Financial literacy in Turkish formal education curriculum. Elementary Education Online, 16(3), 935-948. https://doi.org/10.17051/ilkonline.2017.330233

Helen, T., \& Ilias, S. (2019). Financial literacy of graduate high school students. American Journal of Educational Research, 7(3), 232-236. https://doi.org/10.12691/education-73-7

Henning, M. B., \& Lucey, T. A. (2017). Elementary preservice teachers' and teacher educators' perceptions of financial literacy education. The Social Studies, 108(4), 163-173. https://doi.org/10.1080/00377996.2017.1343792

Imelda, C. M., Angeline, M. P., Gwendelina, A. V, \& Genalen, M. P. (2017). Financial literacy of professional and pre-service teachers in the Philippines. Journal of Global Economics, 05(04). https://doi.org/10.4172/2375-4389.1000267

Jones, H., \& Twiss, B. C. (1978). Forecasting technology for planning decisions [No. 658.4 J6]. New York: Macmillan.

Julius, K., Birekeraho, S. J., \& Kabuto, A. B. (2020). A competence based curriculum in teaching financial education-what happens in classrooms? International Journal of Accounting and Finance Studies, 3(2), 1-9. https://doi.org/10.22158/ijafs.v3n2p1

Liu, C. L., Chang, D. F., \& Chuang, C. M. (2019). Investigation of the financial literacy among high school students. ICIC Express Letters, Part B: An International Journal of Research and Surveys, 10(5), 387-393. https://doi.org/10.24507/icicelb.10.05.387

Malaysian Department of Insolvency. (2020). Bankruptcy statistics 2020. Retrieved from http://www.mdi.gov.my/images/documents/Statistics/Bankrupcy/BRIEFNOTEKEBANK RAPANDISEMBER2020.pdf

Matheson, M. N., DeLuca, C., \& Matheson, I. A. (2020). An assessment of personal financial literacy teaching and learning in Ontario high schools. Citizenship, Social and Economics Education, 19(2), 118-132. https://doi.org/10.1177/2047173420927665

McGregor, S. L. T. (2018). Status of consumer education and financial education in Canada (2016). Canadian Journal of Education, 41(2), 601-632.

Ministry of Education Malaysia. (2018). 2017 Annual report: Malaysia education blueprint 2013-2025. Putrajaya: Education Performance and Delivery Unit (PADU). https://www.padu.edu.my/wp-content/uploads/2018/07/AR2017-English-PPPM-.pdf

Jamil, M. R., \& Noh, M. N. (2020). Kepelbagaian metodologi dalam penyelidikan reka bentuk dan pembangunan. Shah Alam: Qaisar Prestige Resources.

Mohd Jamil, M. R., Siraj, S., Yusof, F., Mat Noh, N., Hussin, Z., \& Sapar, A. A. (2015). Aplikasi teknik fuzzy delphi terhadap keperluan elemen keusahawanan bagi pensyarah kejuruteraan politeknik Malaysia. International Journal of Business and Technopreneurship, 5(1), 135-150.

Novieningtyas, A. (2018). Pentingnya edukasi literasi keuangan sejak dini. Manners, 1(2), 133137.

O’Neil, M. J., \& Jackson, L. (1983). Nominal group technique: A process for initiating curriculum development in higher education. Studies in Higher Education, 8(2), 129138. https://doi.org/10.1080/03075078312331378994

OECD/INFE. (2018). OECD/INFE toolkit for measuring financial literacy and financial inclusion. OECD/INFE toolkit for measuring financial literacy and financial inclusion. Retrieved from https://www.oecd.org/financial/education/2018-INFE-FinLit-MeasurementToolkit.pdf 
OECD. (2018). PISA 2018 released financial literacy items. Organisation for Economic Cooperation and Development. Retrieved from https://www.oecd.org/pisa/test/PISA2018-financial-literacy-items.pdf

OECD, \& GFLEC. (2018). Effective financial education for sustainable and inclusive growth. In Proceedings of the 5th OECD-GFLEC Global Policy Research Symposium to Advance Financial Literacy. OECD Conference Centre, Paris, France, 18 May 2018. Washington, DC: Global Financial Literacy Excellence Center.

Ramli, M. S., \& Mohd Tajudin, N. (2021). Need analysis for developing a Challenge-Based Learning Module in learning Mathematics for form 4 students. Jurnal Pendidikan Sains \& Matematik Malaysia, 11, 50-58. https://doi.org/10.37134/jpsmm.vol11.sp.5.2021

Richey, R. C., \& Klein, J. D. (2007). Design and development research. Mahwah, NJ: Lawrence Erlbaum Associates Publishers.

Richey, R. C., Klein, J. D., \& Nelson, W. A. (2004). Developmental research: Studies of instructional deisgn and development. In D. H. Jonassen (Ed.), Handbook of research on educational communications and technology (2nd ed., pp. 1099-1130). Mahwah, NJ: Lawrence Erlbaum Associates, Publishers.

Salas-Velasco, M., Moreno-Herrero, D., \& Sánchez-Campillo, J. (2020). Teaching financial education in schools and students' financial literacy: A cross-country analysis with PISA data. International Journal of Finance and Economics, June 2018. https://doi.org/10.1002/ijfe.2005

Sawatzki, C., \& Sullivan, P. (2017). Teachers' perceptions of financial literacy and the implications for professional learning. Australian Journal of Teacher Education, 42(5), 51-65. https://doi.org/10.14221/ajte.2017v42n5.4

Siraj, S., Abdullah, M. R. T. L., \& Muhamad Rozkee, R. (2020). Pendekatan penyelidikan reka bentuk dan pembangunan: Aplikasi kepada penyelidikan pendidikan. Tanjong Malim: Universiti Pendidikan Sultan Idris.

Siraj, S., Alias, N., DeWitt, D., \& Hussin, Z. (2013). Design and development research: Emergent trends in educational research. Kuala Lumpur: Pearson Malaysia.

Tanase, M. F., \& Lucey, T. A. (2017). Pre-service teachers' awareness of interdisciplinary connections: Mathematics, financial literacy, and social justice issues. Investigations in Mathematics Learning, 9(1), 2-18. https://doi.org/10.1080/19477503.2016.1245027

Van den Akker, J., Gravemeijer, K., \& McKenney, S. (2006). Introducing educational design research. In J. van den Akker, K. Gravemeijer, S. McKenney, \& N. Nieveen (Eds.), Educational design research (pp. 15-19). London: Routledge. https://doi.org/10.4324/9780203088364-9

Zaimah, R., Sarmila, M. S., Azima, A. M., Saad, S., Lyndon, N., Hussain, M. Y., \& Selvadurai, S. (2012). Financial behaviour of teachers in Bandar Baru Bangi, Selangor, Malaysia. Geografia: Malaysian Journal of Society and Space, 8(6), 42-48.

https://doi.org/10.5539/ass.v9n8p34 